\title{
MUSIK ETNIK DAN PENGEMBANGAN MUSIK GEREJA
}

\author{
M. Hari Sasongko \\ Dosen Pascasarjana Musik Gereja STT Abdiel \\ michaelhari.sas@gmail.com
}

\begin{abstract}
Abstrak
Gereja sebagai lembaga keagamaan dan musik etnis, sebagai produk kreatif masyarakat adalah dua hal yang sangat berbeda, baik dari segi filosofis, makna, eksistensi, entitas, maupun dari segi sosial dan kesejarahan, bahkan secara ideologis kedua hal ini saling menegasikan satu sama lain. Akan tetapi, walaupun keduanya acapkali bertentangan, keduanya memiliki kepentingan dan tujuan yang sama, yakni tempat berkumpulnya manusia untuk mengekspresikan jatidiri mereka. Ketika keduanya bertemu, mereka menciptakan sesuatu yang baru. Berdasarkan teori Homi K. Bhabha, sesuatu yang baru itu disebut "ruang ketiga" yang di dalamnya mencakup karakter ambivalensi dan mimikri. Dalam perspektif musikologis, hibridasi antara gereja dan musik etnis menghasilkan genre baru yakni "musik etnik gereja". Genre baru ini terbukti mampu meningkatkan suasana ibadah di gereja.
\end{abstract}

Kata kunci: genre; gereja; musik etnik; ruang ketiga

\begin{abstract}
Church, as a religious institution, and ethnic music, as a communality creation, are different thing. They have different philosophy, meaning, existence, entity, form, and also sosial and historical context. Sometimes even as, ideologically, they display even negation. However inspite of the contradiction, they have some interest and orientation i.e. come together on a place for expressing who people are. When they meet, there, they create something new. Based on Homi K. bhabha's theory, this something new is called "the third space". We will find ambivalence and mimicry in the new space. On the musical perspective, the hybrid of church and ethnic music call into being a new genre, namely "ethnical church music". The cutting-edge genre proved succeed for increasing worship atmosphere.
\end{abstract}

Keywords: genre; church; ethnic music; the third space

\section{Pendahuluan}

Musik dan gereja adalah dua hal yang tidak dapat dipisahkan. Itulah sebabnya agama Kristen sering disebut "agama yang bernyanyi". Musik di dalam gereja memiliki peran yang sangat signifikan dan menentukan di dalam keberhasilan sebuah ibadah. Peran musik di dalam gereja ini secara historis telah dikembangkan secara serius pada Abad Pertengahaan Fase Pertama oleh para Bapa Gereja, terutama oleh Paus Gregorius Agung. Paus ini mulai menyaring, menyusun, menstandarisasi musik-musik liturgi gereja yang 'berserakan' di berbagai wilayah dari masa gereja perdana. Dari situ gereja memiliki kekayaan estetika musik pertama dengan munculnya musik Gregorian (Gregorian chant) dengan berbagai modusnya yang khas dengan syair berbahasa Latin. Pada masa reformasi di masa Renaisans, tradisi ini didekonstruksi oleh Martin Luther, akan tetapi dengan tidak mengubah peran dan eksistensi musik itu sendiri di dalam gereja. Luther mulai 
membongkar tradisi musik gereja yang berkembang saat itu dengan melibatkan musikmusik yang berkembang di masyarakat Jerman. Disadari/ tidak, sebenarnya peristiwa ini adalah peristiwa inkulturasi musik gereja pertama. Di sini tampak bahwa gereja mulai keluar dari lingkaran tradisi musikalnya yang cenderung formal, terbatas dalam hal kreativitas dan kaku, namun tetap bernuansa Eropa.

Seiring berjalannnya waktu yang hampir setengah milenium, gereja Kristen pun berkembang ke semua penjuru dunia, dan Injil pun telah diwartakan dan banyak diterima oleh masyarakat di wilayah luar Eropa, termasuk Indonesia. Di sinilah terjadi 'pertemuan budaya', bukan hanya dari aspek ideologi, sosial, tradisi dan tata cara ibadah, tetapi juga tradisi musikal. Budaya Kristen yang berkarakter Eropa itu bertemu dengan budaya lokal yang dari banyak aspek memang sangat berbeda, termasuk pandangan-pandangan atau konsep-konsep musikalnya. Maka terjadilah inkulturasi budaya yang sebenarnya tidak jauh berbeda konteksnya dengan pada masa Luther dulu.

Dari perspektif musikologis, kini konsep diatonis bertemu dan berinteraksi secara korelatif dengan konsep pentatonis yang berarti juga pertemuan dan interaksi antara dua model instrumen musik yang berbeda; dua konsep yang secara filosofis pun berbeda. Gereja yang lekat dengan instrumen piano, organ, dan choir, kini berhadap-hadapan dengan gamelan, gondang, pesinden, sape, dan sebagainya. Secara faktual gereja tentu saja tidak mungkin memungkiri kenyataan ini. Dalam konteks eksistensi gereja Kristen di Indonesia, kenyataan yang lain adalah bahwa gereja secara yuridis-formal berada di wilayah dan pemerintahan yang disebut 'Indonesia', dengan masyarakat yang disebut 'Indonesia', dan budaya 'Indonesia'. Inkulturasi budaya menjadi sangat penting dalam rangka memperkenalkan dan mempertobatkan mereka yang belum mengenal dan mengimani Kristus.

Di dalam tulisan ini akan diulas lebih dalam mengenai fenomena pertemuan tersebut - terutama dalam konteks musikal — yang pada gilirannya memberikan peran yang cukup signifikan di dalam membangun semangat dan spiritualitas di dalam ibadah Kristen, yang secara bersamaan dapat dipakai sebagai acuan dalam mengembangkan musik di gereja Kristen. Judul tulisan ini pun telah mengisyaratkan adanya sebuah pertemuan yang muncul di dalam dua variabel yakni 'musik etnik' dan 'musik gereja'. Oleh karena itu agar tidak mengundang perbedaan persepsi dan interpretasi yang cukup tajam, pembahasan di dalam tulisan ini akan dimulai dengan membahas terlebih dahulu yang disebut 'musik etnik' dan 'musik gereja'. 
Setelah itu 'pertemuan dua tradisi musik' ini dianalisis berdasarkan teori pascakolonial (post-colonialism) Homi K. Bhabha. Teori pasca-kolonial Bhabha pada dasarnya merupakan teori inkulturasi kebudayaan yang banyak dipakai di bidang-bidang seni dan humaniora, termasuk bidang politik. Konsep pertemuan dua budaya dari Bhabha meliputi konsep hibrida (hybrid), ambivalensi (ambivalence), mimikri (mimicry), dan ruang ketiga (the third space). Pengembangan musik gereja dapat dilihat berdasarkan pembahasan mengenai 'ruang ketiga' dari teori Bhabha tersebut. Dari analisis ini maka dapat diambil kesimpulan berkaitan dengan objek material di atas pada bagian penutup.

\section{Musik Etnik}

Secara sederhana, musik etnik adalah musik yang dimiliki, dikembangkan, dikenal dengan baik, dan lazim dipakai oleh etnis tertentu, untuk kepentingan tertentu. Kajian tentang musik etnik berada di dalam khazanah etnomusikologi. Istilah 'etnomusikologi' (etnomusicology) pertama kali diperkenalkan oleh musikolog Belanda Jaap Kunst pada awal Abad 20 untuk menyebut nama lain dari "musikologi komparatif" (comparative musicology) atau "antropologi musik". Etnomusikologi pada dasarnya adalah sebuah pendekatan (approach) yang dipakai bukan hanya untuk musik itu sendiri, tetapi juga musik di dalam sebuah konteks kebudayaan.

Secara garis besar, studi etnomusikologi adalah (1) studi tentang semua musik di luar musik Barat, tetapi mencakup musik-musik rakyat Eropa, (2) studi tentang musik yang berada di lokal tertentu yang bercirikan musik rakyat, musik popular, musik industri, dan musik hibrida (hybrid) (Hood, 1972, p. 298). Beberapa musikolog pernah menyebut etnomusikologi adalah studi tentang "musik eksotis", akan tetapi pandangan ini banyak ditentang karena istilah 'eksotis' berkonotasi 'primitif', 'terbelakang', yang cenderung merendahkan, padahal tidak sedikit musik etnik yang secara teknis-musikologis lebih rumit dibandingkan musik Barat.

Nettl (1983, p. 137) menyebut, etnomusikologi adalah studi tentang hubungan yang tak terpisahkan antara teks musik dan konteks musik; "it is focused on the interrelationships and interdependencies between text and context in music and they supported each other". Willi Apel senada dengan Krader, mengungkapkan definisi yang cukup umum bahwa 'etnomusikologi' adalah suatu kajian yang mempelajari tradisi musikal di luar tradisi musik yang dikembangkan sejak masa Renaisans (Supanggah, 1995; Nettl, 1964). Oleh karena itu, pembahasan mengenai peran musik etnik di dalam 
pengembangan musik gereja pada dasarnya berada di dalam khazanah atau studi etnomusikologi; musik etnik sebagai teks dan gereja sebagai konteks.

Akan tetapi, oleh karena begitu luasnya cakupan studi ini, maka seringkali tidak menempatkan studi ini pada batasan objek material yang jelas, terutama dalam hal istilah yang berkembang di masyarakat. Dalam hal ini tidak sedikit orang yang menyamakan begitu saja antara musik rakyat, musik tradisional, dan musik etnik sehingga pengertiannya menjadi kacau, padahal ketiga jenis musik ini memiliki esensi yang sangat berbeda. Oleh karena itu pengertian ketiga istilah di atas harus dibahas secara tersendiri agar tidak terjadi kesimpangsiuran pemahaman.

'Musik rakyat' adalah sebuah istilah yang sangat umum sebab kata 'rakyat' di sini juga bersifat sangat umum dan tidak merujuk pada suatu kelompok yang jelas. Rakyat bisa dari berbagai lapisan. Para penggemar dangdut, jazz, campursari, gamelan jawa, lagu-lagu tradisional, penggemar musik klasik bisa disebut 'rakyat'. Mereka yang berada di bawah garis kemiskinan (bawah), yang berekonomi pas-pasan atau cukup untuk memenuhi kebutuhan sehari-hari (menengah), atau mereka yang memiliki banyak harta (atas) disebut juga 'rakyat'. Itu baru berdasarkan klasifikasi kelas sosial dan selera musik, dan belum berdasarkan klasifikasi agama, suku, agama, teritorial, bahasa, dan sebagainya. Akan tetapi pada umumnya yang dimaksud 'rakyat' di sini adalah masyarakat kebanyakan yang tergabung dalam kelompok kaum urban. Dangdut (termasuk dangdut koplo), keroncong, pop Jawa, pop Batak, dan sebagainya bisa disebut musik rakyat.

Konsep musik rakyat di atas secara lebih spesifik juga dapat diartikan bahwa musik tersebut sangat erat kaitannya dengan budaya massa (mass culture). Musik jenis ini biasanya dinegasikan dengan 'high culture': musik kelas atas, kelas bangsawan, kelas kaum terdidik atau akademis (educated class). Walaupun punya standarisasi dan kadang-kadang konservatif, musik jenis ini bersifat sangat dinamis lantaran ditopang oleh media massa sehingga tidak lagi bersifat asli, seperti dikatakan Lowenthal (1985, p. 55) bahwa " $A$ product of popular culture has none of the feature of genuine art, but in all its media popular culture prove to have its own genuine characteristics: standardization, stereotypy, concervatism, mendacity, manipulated consumer goods" (lihat juga Gans, 1974; Adorno, 1985, p. 474-488). Yang perlu dicatat mengenai pengertian 'standardization' di sini adalah standarisasi berdasarkan kepentingan industri, dan bukan standarisasi yang berkaitan dengan nilai estetis. Itu sama halnya, nilai estetis musik rakyat sangat tergantung dari tingkat kepentingan industri atau lebih tepatnya si pemilik modal (Lowenthal, 1985, p. 57). 
Oleh karena itu ciri khas musik ini adalah bersifat masif dan oleh karenanya nilai estetis musik ini tergantung pada tingkat kepopuleran seseorang atau kelompok musik (wellknown).

'Musik tradisional' memiliki makna yang lebih spesifik. Dari istilahnya saja dapat dilihat bahwa musik ini hadir di dalam konteks tradisi tertentu, dalam arti diwariskan secara turun-temurun di dalam suatu kelompok masyarakat tertentu, dari satu generasi ke generasi selanjutnya. Oleh karena merupakan warisan, maka eksistensi musik ini sangat tergantung pada 'pengakuan' masyarakat tersebut atas musik tertentu atau berdasarkan titah seorang penguasa lokal. Seseorang tidak dapat begitu saja menciptakan musik tradisional sebab harus ada pengakuan dari masyarakatnya dan 'pengakuan' tersebut bisa terjadi ratusan tahun kemudian setelah diwariskan secara turun-temurun. Jadi eksistensi musik ini sangat tergantung pada klaim suatu masyarakat terhadap musik (lagu) tertentu. Akan tetapi ada juga yang langsung diakui sebagai musik tradisional karena wewenang seorang penguasa lokal. Misalnya komposisi musik untuk iringan tari Bedoyo Ketawang yang dianggap sakral oleh masyarakat Jawa, langsung disebut 'musik tradisional' setelah diciptakan lantaran titah Sri Sultan Hamengkubuwono IX sebagai seorang raja Jawa. Oleh karena diciptakan oleh golongan ningrat, kaum bangsawan, maka seringkali musik tradisional dianggap bersifat 'adiluhung', 'mulia', 'keraton sentris', dan top-down dari segi nilai estetis yang ditandai dengan adanya 'pakem'.

Menurut Kunst, masalah di dalam musik tradisional adalah justru karena musik itu berada di dalam konteks kebudayaan yang bersifat 'tradisional'. Tradisi atau hal-hal yang bersifat tradisional seringkali dianggap mewakili konservatisme pandangan terbelakang, yang celakanya sangat memiliki establishment. Dari satu sisi, dari perspektif modernitas, jika orang Jawa, sebagai misal, mempertahankan tradisinya sering ditafsirkan sebagai sudut pandang yang kolot. Tidak seperti budaya Barat yang fleksibel, 'dapat berubah' dan mudah menerima penetrasi kebudayaan dari luar dirinya, seni tradisi lebih bersifat establish, konstan, karena segala sesuatunya lebih berorientasi pada kepentingan komunal. Oleh karena itu tidak terlalu mengherankan jika istilah 'tradisi' menjadi lebih berkonotasi adanya keotentikan, turun-temurun, berkaitan dengan kesinambungan generasi komunal, dan kekunoan, bahkan tidak jarang kesenian tradisional dihubungkan dengan segala

${ }^{1}$ Dalam tradisi Jawa semacam pedoman, aturan, petunjuk pelaksanaan, atau term of references yang merupakan kesepakatan bersama yang disusun oleh mereka yang dianggap sebagai empu, begawan, atau para cerdik cendikia keraton, yang wajib ditaati dan tidak boleh dilanggar. Pakem bukan hanya ada di dalam gamelan atau karawitan, tetapi juga di pewayangan, ritual adat, tari, slametan, ruwatan, dan sebagainya. 
sesuatu yang bersifat eksotik. Masalahnya menjadi semakin rumit jika fenomena ini ditempatkan dalam konteks 'pelestarian'. Istilah pelestarian mengacu pada tindakan pemeliharaan dan pengembalian kembali. Pelestarian berasal dari kata dasar 'lestari' yang berarti 'kekal'; 'tidak berubah'. apa yang disebut 'perubahan' (Kunst dalam Lindsay, 1989, p. 26). Dapat dimaklumi jika konsep ini bertentangan dengan jiwa dan semangat pergerakan kebangsaan yang jelas-jelas memperjuangkan perubahan.

Yang terakhir adalah 'musik etnik'. Dari istilahnya saja dapat dilihat bahwa musik ini adalah musik yang sangat berkaitan dengan etnis tertentu. Artinya, jenis musik ini sangat tergantung pada ideologi atau cara pandang, atau spiritualitas suatu etnis terhadap suatu hal. Salah satu ciri musik etnik adalah penggunaan tangga nada pentatonis. Penggunan modus pentatonis ini diwujudkan melalui identitas instrumen yang digunakan. Secara faktual, biasanya musik etnik tidak berdiri sendiri, melainkan hadir secara holistik bersama kesenian lain seperti tari dan drama, bahkan hadir di dalam konteks upacara keagamaan atau kepercayaan tertentu.

Secara filosofis, nada-nada yang digunakan atau idiom-idiom yang berlaku merupakan representasi dari nilai-nilai filosofi yang diyakini di dalam suatu etnis tertentu yang terwujud dalam konsep moralitas, kebaikan, keutamaan, atau etika. Sebagai contoh, moralitas di dalam kebudayaan Jawa banyak bersumber pada cerita-cerita pewayangan dan mengadopsi karakter-karakter tokoh di dalam cerita Mahabharata dan Ramayana. Maka kehadiran lima nada, pelog atau slendro di dalam musik etnik Jawa misalnya, sering dikaitkan dengan tokoh Pandawa Lima dalam kisah Mahabharata (Sudarto, 2000, p. 157170). Fenomena musik rakyat ini sangat cocok jika dikaitkan dengan pandangan bahwa musik merupakan konstruksi ideologi, seperti diungkap Janet Wolff (1993), “... the possibility of the radical potensial of art is itself historically determined, and that there is no contradiction between the view that art is socially and ideologically constructed".

Oleh karena dimikili oleh etnis tertentu, maka biasanya bahasa yang digunakan juga bahasa yang lazim digunakan oleh etnis tersebut sebagai sarana perwujudan identitas dan kreativitas. Pada dasarnya tidak banyak perbedaan antara musik tradisional dengan musik etnik, atau sekurang-kurangnya perbedaan itu tidak terlalu tajam. Yang membedakan, tetapi justru bersifat prinsip, adalah musik etnik lebih terbuka terhadap idiom-idiom musik lain karena memungkinkan adanya pertemuan dengan kebudayaan lain, dan karena itu pula yang menjadi sebab musik ini disebut 'musik plural'. Keterbukaan ini sangat dimungkinkan karena musik etnik lebih bersifat bottom-up. Walaupun kini musik etnik 
juga masuk ke dalam wilayah mass culture, akan tetapi ciri khas musik ini, terutama idomidiom musikal tetap bisa dipertahankan.

\section{Musik Gereja}

Musik gereja adalah varian dari musikologi atau wacana musikal yang belum banyak dibahas orang atau para musikolog secara menyeluruh; dari berbagai aspek, padahal memiliki perkembangan yang luar biasa seiring dengan perkembangan gereja. Di Indonesia, catatan-catatan atau manuskrip-manuskrip mengenai musik gereja di gerejagereja bisa dikatakan sedikit sekali, kalau tidak boleh dibilang tidak ada. Yang ada hanya diskografi, itu pun baru merebak belakangan ini dengan hadirnya rekaman aktivitas bermusik di gereja lewat sosial media.

Selain itu, hasil penelitian tentang musik gereja oleh para sarjana musik gereja pun boleh dibilang sangat minim. Sekurang-kurangnya terdapat tiga kemungkinan berkaitan dengan fenomena ini, pertama, musik gereja dipandang semata-mata aktivitas bermusik di gereja, dalam arti, hanya urusan kegiatan orang bermain musik di dalam gereja sehingga dianggap tidak perlu kajian-kajian mendalam; kedua, musik di gereja hanya berfungsi untuk mengiringi atau mendampingi orang beribadah sehingga dianggap bukan main topic dalam sebuah ibadah; ketiga, walaupun sudah relatif banyak bermunculan program studi musik gereja di banyak sekolah tinggi teologi, stigma bahwa kegiatan bermusik di gereja hanya sebuah 'sambilan' tampaknya tidak mudah untuk dihapus. Hal itu ditandai dengan sering munculnya ungkapan, "kalau hanya untuk bisa bermain musik di gereja, untuk apa masuk program studi musik gereja? Bukankah bisa lewat kursus musik saja?"

Akibat dari tiga kemungkinan di atas, maka istilah 'musik gereja' seringkali diartikan secara simplistis sehingga memiliki makna definitif yang cenderung dangkal. Musik gereja sering diartikan sebagai "musik yang dimainkan di dalam gedung gereja", "musik untuk kepentingan ibadah Kristen", "musik untuk menyembah Tuhan Yesus", "musik untuk menuji dan memuliakan Allah", "musik yang terdapat di dalam rangkaian liturgi Kristen”, dan sebagainya, bahkan dalam dunia akademis lebih sederhana lagi, yakni "pelajaran musik sekular yang disertai pelajaran teologi”. Semua pengertian di atas tentu saja tidak salah dan memang begitu kenyataannya. Pandangan-pandangan di atas pun tidak bertentangan dengan Alkitab. Misalnya lewat cerita ketika Musa dan bangsa Israel menyanyikan lagu kemenangan atas Mesir (Kel. 15:1-21); menyanyikan lagu syukur atas air yang diberikan Tuhan (Bil. 21:17). Dalam dua peristiwa itu semua orang ikut serta 
merayakan karya besar Tuhan. Juga ungkapan "jiwaku menyanyikan mazmur bagiMu (Mzm. 30:13) dan juga (Mzm. 150:3-5).

Akan tetapi agar pengertian-pengertian tersebut bisa menyentuh hakikat 'musik gereja' yang sebenarnya, maka sudah seyogianya jenis musik ini ditelaah lebih dalam. Upaya ke arah itu harus dengan cara mendeteksi ciri-ciri musik gereja itu sendiri mengingat perkembangan gereja Tuhan yang luar biasa yang tentu saja berdampak pada semua aspek sekundernya. Robert Berglund (1985, p. 5-17) mengungkapkan ciri-ciri musik gereja sebagai berikut.

1. Bersifat Rohaniah.

Artinya musik ini dihadirkan berkaitan dengan kebutuhan rohani manusia, kebutuhan akan berkomunikasi dengan yang Transenden, penciptanya, yakni Allah Bapa yang Mahakuasa. Bersifat rohaniah menunjukkan bahwa musik ini tidak ditujukan untuk kegiatan-kegiatan sekular, dan justru sebaliknya, menunjukkan adanya spiritualitas tertentu. Kendrick (1984, p. 83) memaknai spiritualitas itu sebagai penyembahan di dalam Roh (Yoh. 4:24). Musik yang tidak bersifat rohani dan tidak bersandar pada Alkitab sebagai dasar spiritualitas Kristen tidak bisa dan tidak boleh disebut sebagai musik gereja.

\section{Alkitabiah}

Seperti halnya gereja, musik gereja haruslah bersumber dari dan bersandar pada Alkitab. Musik yang tidak bersumber dari Alkitab berarti bukan musik gereja. Itu berarti setiap pesan dan moralitas yang terkandung di dalam musik itu tidak bertentangan dengan isi Alkitab, bahkan secara lebih spesifik bersumber dan mengarah pada pribadi Yesus Kristus yang telah dinubuatkan sejak zaman nabi di Perjanjian Lama. Kata "bersumber" di sini tidak harus mengutip setiap kata di dalam Alkitab untuk kepentingan syair lagu, melainkan harus dimaknai bahwa Alkitab sebagai sumber inspirasi sehingga menjadi 'jiwa' dari setiap lagu. "Tidak harus” berarti boleh juga menggunakan Alkitab sebagai sarana ilustrasi dalam komposisi musiknya.

\section{Dimainkan di Hadapan Jemaat Kristus}

Musik gereja adalah musik yang dihadirkan di dalam persekutuan orang yang beriman kepada Kristus. Ini sama halnya bahwa musik ini hadir dalam konteks ibadah; di sinilah musik gereja menemukan maknanya sebagai musik ibadah Kristen. Walaupun syair-syairnya berlandaskan Alkitab, akan tetapi jika musik ini dimainkan di tempat-tempat yang tidak layak seperti di cafe-cafe atau tempat-tempat yang dekat dengan kedosaan, 
maka musik itu juga tidak boleh disebut musik gereja, bahkan sudah menuju pada tindakan penghinaan kepada Allah sendiri.

\section{Musik Gereja seharusnya dapat Membangun Suasana Ibadah/ Suasana Liturgis}

Suasana ibadah di sini bernuansa relatif, tergantung dari tradisi gereja masingmasing. Yang jelas, musik ini harus mampu membangun suasana tertentu, sehingga jemaat merasakan nyaman dalam beribadah. Ibadah kristen menurut George Florovsky adalah jawaban manusia terhadap panggilan ilahi; terhadap tindakan-tindakan yang penuh kuasa Allah, yang berpuncak dalam tindakan perdamaian dalam Kristus (1995, p. 52). Jadi ibadah kristen di gereja merupakan respon dari ciptaan kepada pencipta yang telah menyelamatkan kehidupan manusia yang berdosa melalui suatu kegiatan yang ditata sedemikian rupa, sehingga jemaat dapat bersama-sama memberikan syukur, pujian dan penyembahan. Oleh karena itu suasana ibadah Kristen harus dilakukan secara teratur dan dipersiapkan dengan baik. Tujuannya agar jemaat dapat beribadah dengan penuh ketulusan, semangat, khidmat, dan suka cita. Indikator suasana ibadah kristen dapat dilihat dari liturgi yang baik, berkaitan dengan nyanyian, musik, dan penyampaian Firman Tuhan.

\section{Musik Gereja Harus Mampu membawa Jemaat Masuk ke dalam Hadirat Allah}

Hal ini berarti musik gereja harus mampu membangun suasana di mana jemaat merasakan sukacita, kebebasan, dan damai sejahtera. Tetapi yang lebih penting, dengan hadirat Allah, jemaat dapat diubah cara berpikir, cara bertindak, dan cara merasakan melalui pertobatan hidup ke arah yang lebih baik. Dengan pertobatan itu sejatinya manusia telah dibebaskan. Bukankah Tuhan datang untuk kebebasan manusia dari dosa itu?

Namun demikian, oleh karena musik gereja di Indonesia adalah bagian dari musik Indonesia, maka karakter musik ini pun tidak bisa dilepaskan dari karakter musik Indonesia itu sendiri. Musik Indonesia_-dalam arti yang berada di Indonesia dan berbahasa Indonesia-yang digunakan oleh gereja-gereja di Indonesia sebetulnya memiliki cacat primordial. Secara historis perkembangannya bersifat temporal dan pragmental. Suka Hardjana (1995) mencatat sebagai berikut.

\footnotetext{
Musik Indonesia lahir tanpa akar dan konsepsi dasarnya, terutama sekali karena kita memang bukan menjadi bagian dari semangat lahirnya peradaban Renaisans, di mana musik Barat itu ditumbuhkembangkan. Yang terjadi kemudian adalah nilai cangkokan yang (walaupun menumbuhkan rasa sayang dan senang kepalang tanggung, tapi) tidak pernah dapat berdiri sendiri, sehingga yang berkembang adalah fragmen-fragmen tren musik yang terpenggalpenggal dan tidak berkesinambungan satu sama lain.
} 
Jadi sebetulnya musik-musik yang dipakai di gereja-gereja di Indonesia-yang berbahasa Indonesia-merupakan musik cangkokan (hybrid) juga. Namun demikian menurut Suka, itu lebih baik ketimbang mengambil begitu saja secara mentah-mentah musik Barat yang mengakibatkan musik itu sendiri teralienasi dari lingkungan sosialnya.

\section{Teori Post-colonialism Homi K. Bhabha}

Homi K. Bhabha adalah filsuf, sastrawan, kritikus sastra dan budaya, dan aktivis kemanusiaan yang lahir di India pada abad 20, namun berkebangsaan Inggris. Teori-teori kebudayaannya sangat berpengaruh di kalangan kaum humanis dan masuk dalam aliran poskolonialisme. ${ }^{2}$ Pandangan-pandangan dasarnya merupakan reaksi dari kondisi kronis negara dunia ketiga, baik secara kultural maupun ideologis akibat praktik penjajahan. Menurut Gandhi (1998, p. 12-22), poskolonialisme menjadi sangat 'manusiawi' melalui pemikiran-pemikiran Bhabha. Pemikirannya lebih jernih dan menyingkirkan apriori-apriori sehingga 'perdamaian' dua kebudayaan dapat berlangsung secara masuk akal, dinamis, adekuat, dan tidak saling menjatuhkan.

Seperti telah diungkapkan pada bagian pendahuluan, konsep pertemuan dua budaya Bhabha meliputi konsep hibrida (hybrid), ambivalensi (ambivalence) dan mimikri (mimicry). Konsep-konsep tersebut merupakan sifat yang tidak dapat dipisahakan satu dengan yang lain — saling berkorelasi. Korelativitas ini harus dipahami secara menyeluruh.

Hibrida (hybrid) adalah sebuah istilah untuk mengungkap adanya suatu perkawinan silang, atau dalam biologi biasa disebut 'cangkokan'. Istilah biologis ini dipakai Bhabha dalam konteks kebudayaan, terutama untuk memahami fenomena pertemuan dua kebudayaan. Menurut Bhabha, hibriditas pada dasarnya merupakan perkawinan silang antara dua makhluk yang saling bertolak belakang, bahkan bertentangan (ambivalence), baik secara jenis maupun sifat, namun memiliki reciprocality (ketergantungan satu dengan yang lain), sehingga menghasilkan keturunan yang di satu sisi memiliki, namun di sisi lain tidak memiliki sifat kedua orangtuanya; neither the one nor the other (1994, p. 37). Dalam 'perkawinan dua kebudayaan' ini, kebudayaan pertama disebut 'penjajah' (colonizer), sedangkan yang kedua disebut 'yang terjajah' (colonized). Anak dari hasil perkawinan

${ }^{2}$ Teori Bhabha memang masuk ke dalam wilayah post-colonial. Akan tetapi kata 'post' di sini sama sekali tidak terkait dengan pengertian "periode setelah kolonial", melainkan merujuk pada pengertian 'melampaui'. Jadi post-colonial berkaitan dengan istilah beyond bukan after. 
silang ini adalah hibrida; makhluk yang sama sekali berjenis baru, yang unik, yang mampu 'mencairkan' perbedaan yang dimiliki kedua orangtuanya.

Menurut Bhabha, proses hibrida tidak berlangsung karena paksaan, entah yang bersifat sosial, politis, kultural, maupun ideologis. Bhabha mamahami bahwa hibriditas tersebut lahir karena adanya 'negosiasi', “... there can no negation of trancendence of difference" (1994, p. 54). Makhluk hibrida yang dimaksud di atas tadi merupakan hasil dari proses negosiasi.

Pada saat yang sama, makhluk hibrida tadi berada pada ruang yang berbeda dengan ruang tempat orangtuanya berada. Ia berada dalam suatu ruang 'privacy' yang sama sekali berbeda keadaanya, sebuah ruang tengah kebudayaan (in-between). Ruang tersebut oleh Bhabha (1994, p. 54) disebut sebagai 'ruang ketiga' (the third space) dan di sinilah produk-produk budaya baru muncul; "third space is the site from which the production of cultural difference emerges".

Di sisi lain, hibriditas itu sendiri bersifat mimikri (mimicry). David Huddart mencatat, di dalam mimikri terdapat tiruan atau pengulangan satu dengan yang lain dari berbagai aspek, termasuk simbol-simbol di dalamnya, walaupun tidak selalu persis, “... an exaggerated copying of language, culture, manners, and ideas. This exaggeration means that mimicry is repetition with difference" (2006, p. 56). Dalam polaritas biner, unsur yang saling bertolak belakang malah seringkali justru saling menguntungkan. Teori Bhabha dapat digambarkan lewat dua buah lingkaran yang bertumpangan. Hasil pertumpangan kedua lingkaran tersebut melahirkan suatu wilayah atau ruang.

\section{Musik Etnik dalam Ibadah Kristen}

Pada bagian ini teori Bhabha tersebut dapat dipakai sebagai instrumen untuk memahami lebih dalam tentang fenomena 'pertemuan' atau 'perkawinan' antara musik etnik dan musik gereja. Dalam konteks teori hibrida, kehadiran musik etnik diletakkan sebagai colonizer, sedangkan musik gereja sebagai colonized. Musik etnik disebut 'colonizer' karena musik ini datang dan memasuki 'wilayah' tertentu dan dalam konteks tertentu dan 'mengintervensi', begitu pula sebaliknya musik gereja merupakan 'pemilik wilayah' yang diintervensi. Kata 'intervensi' sengaja diberi tanda petik sebab pengertian kata ini bukan berorientasi pada penindasan. ${ }^{3}$ Pada dasarnya kedua hal ini bersifat

\footnotetext{
${ }^{3}$ Wacana kolonial merepresentasikan pandangan si penjajah terhadap yang dijajah sebagai oposisi yang kaku seperti kedewasaan/ ketidakdewasaan, beradab/ biadab, maju/ berkembang, progresif/ primitif.
} 
ambivalen, yakni bertolak belakang baik dari segi jenis maupun sifat, yang dapat dilihat di dalam unsur-unsur keduanya sebagai berikut.

1. Secara musikologis, musik etnik kebanyakan menggunakan tangga nada pentatonis, sedangkan musik gereja umumnya menggunakan tangga nada diatonis.

2. Musik etnik selain sebagai musik sekuler atau musik hiburan yang banyak berkembang belakangan ini, juga tidak jarang dipakai untuk upacara-upacara atau ritual-ritual di luar keyakinan atau iman kristen, penyembahan kepada allah-allah lain, sedangkan musik gereja bersumber dari, untuk, dan oleh Kristus.

3. Berkaitan dengan poin ke 2 , di dalam kedua jenis upacara dan penyembahan (kepada allah-allah lain dan kepada Kristus), menggunakan instrumen musik yang berbeda.

4. Musik etnik banyak dipakai dalam merepresentasikan kebiasaan-kebiasaan yang melibatkan filsafat-filsafat lokal, sedangkan musik gereja lebih bersandar pada Kebenaran Firman yang tertulis di dalam Alkitab, yang dapat ditemukan di dalam syairsyair lagu, baik secara eksplisit maupun implisit.

5. Secara filosofis, musik-musik etnik yang notabene acapkali menjadi bagian yang tak terpisahkan dari upacara tertentu yang sejatinya mengandung cara pandang yang membelenggu, sedangkan musik gereja bersumber pada pembebasan yang dilakukan Allah dengan model filosofi yang terdapat di dalam Alkitab.

6. Masih berkaitan dengan poin sebelumnya, berdasarkan 'filsafat' tertentu, musik etnik cenderung melahirkan kedosaan karena tidak bersumber pada Kristus, sedangkan musik gereja menciptakan pertobatan manusia yang senantiasa dirindukan Allah.

Menurut Teori Bhabha, colonizer dan colonized, keduanya bersifat mimikri, yakni memiliki persamaan materi, sifat dan bentuk di keduanya antara lain:

1. Musik etnik dan musik gereja memiliki materi dasar musikal, yakni melodi, ritme dan harmoni dan sering memiliki bentuk musikal yang sama.

2. Secara filosofis, sering digunakan untuk sarana penyembahan kepada yang transenden.

3. Sama-sama memiliki kebiasaan-kebiasaan yang khas di dalam praksisnya.

4. Sama-sama menggunakan musik sebagai instrumen untuk tujuan yang bersifat sosial.

Tidak demikian halnya dengan poskolonialisme. Poskolonialisme justru melihat hubungan antara si penjajah dan si terjajah berada dalam suatu proses interaktif, dialogis, proses dua arah ketimbang proses sederhana yang aktif-pasif. Ini adalah sebuah proses yang melibatkan negosiasi dan pertukaran yang kompleks. Inti dari pemikiran poskolonial adalah mencoba menunjukkan bagaimana pertemuan kolonial memberikan sumbangan pada transformasi yang saling menguntungkan antara penjajah dan terjajah. 
5. Sama-sama berada di dalam konteks seni pertunjukan, yang mencakup adanya pemain, penonton, dan materi musikal.

6. Secara psikologis, sama-sama memberikan stimulus sehingga memunculkan emosi tertentu bagi yang hadir di sekitar musik itu berada.

Akan tetapi menurut teori Bhabha walaupun kedua hal tersebut bersifat ambivalen dan mimikri, keduanya juga memiliki reciprocality (ketergantungan satu dengan yang lain). Maka, dalam konteks 'persilangan' antara musik etnik dan musik gereja ini lahirlah 'musik etnik di dalam ibadah kristen' sebagai ruang ketiga (the third space). Inilah musik hibrida (hybrid). Berdasarkan teori Bhabha, di dalam ruang ketiga ini musik yang hadir di situ sesungguhnya tidak sepenuhnya musik etnik dan tidak sepenuhnya musik gereja yang lazim dipakai di dalam liturgi Kristen dalam tradisi Eropa, akan tetapi memiliki sifat kedua orangtuanya; neither the one nor the other. Tangga nada pentatonis merupakan salah satu sifat musik etnik sebagai 'orangtua' ruang ketiga, tetapi iman kepada Kristus juga merupakan 'orangtua' ruang ketiga.

Salah satu sifat bawaan lain dari musik gereja adalah bahwa musik ini hanya sekadar sarana, tujuan utamanya adalah Allah sendiri di dalam diri Yesus Kristus (lihat Marinis, 1993, p. 21-34). ${ }^{4}$ Oleh karena itu maka unsur-unsur musik etnik yang terdapat di ruang ketiga itu berada dalam kondisi yang baru, yang dengan demikian memiliki tujuan baru yaitu Kristus. Demikianlah, di dalam ruang ketiga musik etnik bukan lagi musik etnik yang dulu, tetapi telah memiliki wajah baru setelah mengalami transformasi dan transfigurasi. Demikian pula musik gereja, bukan musik gereja yang dulu, yang European minded, melainkan musik gereja dengan idiom-idiom musik, bentuk liturgi, dan suasana ibadah yang baru. Colonizer dan colonized, lewat ruang ketiga, kini tertuju kepada Kristus. Maka dengan demikian sesungguhnya inti dan penyebab lahirnya ruang ketiga itu adalah Kristus sendiri, dan tujuan utamanya adalah pertobatan dan rasa syukur atas karunia

\footnotetext{
${ }^{4}$ Pada dasarnya analisis teks seni pertunjukan harus dikaitkan dengan tiga unsur utama, yakni penonton, pemain, dan materi. Ketiga aspek ini bersifat 'tritunggal' karena tidak bisa dipisahkan satu dengan yang lainnya. Di dalam konteks musik gereja, jemaat yang datang ke gereja tentu tidak untuk menonton pergelaran musik. Maka penonton di dalam ibadah Kristen sebenarnya adalah Allah sendiri. Pandangan ini sejalan dengan pandangan filsuf Soren Kierkegaard, bahwa di dalam ibadah jemaat harus berusaha membuat Allah senang. Allah senang bukan karena Ia terhibur, melainkan karena manusia menanggapi KasihNya dengan sungguh-sungguh. Dengan demikian pemain musik dalam arti definitif dan jemaat yang hadir, keduanya adalah 'pemain', mengingat vokal juga merupakan salah satu instrumen musik: pemain musik adalah jemaat, dari perspektif lain, jemaan juga 'pemain musik'. Oleh karena itu sudah seyogianya jemaat dan 'pemain musik' bermain dengan sungguh-sungguh dan sepenuh hati untuk menyenangkan hati Allah.
} 
Kristus. Kristus adalah dasar dari kreativitas dan inovasi yang berlangsung di ruang ketiga itu.

Oleh karena semuanya telah bertransformasi dan bertransfigurasi menjadi sesuatu yang baru di dalam ruang ketiga, maka sesungguhnya penggunaan idiom musik etnik di dalam ibadah Kristen merupakan genre (lihat Merriam, 1998, p. 485) ${ }^{5}$ tersendiri; sebuah genre baru yang memiliki ciri khas tersendiri yang berbeda dengan musik-musik yang lain. Ruang ketiga sebagai genre ini memunculkan konsekuensi logis terhadap peran pemain musik. Peran musisi bukan lagi sekadar pihak yang 'membantu' jemaat agar mereka merasakan suasana ibadah dengan baik, tetapi lebih dari itu mereka adalah hamba Tuhan yang 'berkotbah' secara tidak langsung melalui bahasa musik karena mendorong jemaat menuju pertobatan dan suka cita di dalam kasih Tuhan melalui musiknya itu. Dengan kata lain, para musisi gereja sejatinya bukan sekadar 'tukang musik' di dalam gereja, tetapi juga hamba Tuhan karena memiliki tanggung jawab yang cukup besar dalam keberhasilan pertobatan jemaat, hanya saja ia memakai bahasa yang berbeda, yakni 'bahasa musik'.

Dengan demikian, pengembangan musik gereja dapat dilakukan berdasarkan ruang ketiga itu, tempat nilai-nilai etnisitas juga berada. Pengembangan dengan melibatkan unsur-unsur etnik di dalam ibadah Kristen secara adequate sama halnya dengan upaya pengembangan musik gereja. Berikut ini adalah beberapa alternatif yang dapat dipakai dalam konteks pengembangan musik gereja tadi, antara lain:

1. Penciptaan komposisi musik gereja dengan melibatkan idiom-idiom etnis (tertentu). Dalam situasi tertentu idiom musik etnik dapat membawa suasana ibadah yang lebih sesuai dengan alam pikir, dunia batin, kebiasaan, dan nilai estetetis di dalam suatu komunitas (etnis) tertentu.

2. Dalam penciptaan komposisi tersebut bisa melibatkan instrumen-instrumen tradisional. Instrumen tradisional bisa menciptakan nuansa kedaerahan sehingga jemaat dapat merasakan 'seperti berada di rumah sendiri'.

3. Penciptaan komposisi musik yang bisa dikolaborasikan dengan jenis-jenis tari-tarian daerah, instrumen pengiringnya pun tidak harus tamborin, atau instrumen-instrumen ala Barat.

${ }^{5}$ Istilah genre /zhän-rӘ/ sebenarnya merupakan istilah umum yang dipakai di bidang musik dan seni-seni yang lain seperti sastra, drama, dan tari. Istilah ini merujuk pada pengertian kategori dan karakteristik seni, terutama dalam hal gaya (style), bentuk (form), dan kandungan atau isi (content). 
4. Komposisi musik untuk ruang ketiga ini akan lebih memiliki nuansa yang khas jika didukung oleh beberapa unsur etnis, seperti pakaian atau hiasan-hiasan etnis.

5. Komposisi musik bisa pula disesuaikan dengan syair-syair musik yang diinspirasikan dari cerita-cerita etnis tertentu dengan tetap menjaga nilai-nilai spiritualitas Kristen.

6. Komposisi musik etnik untuk ibadah bisa diciptakan sesuai dengan drama atau fragmen yang terdapat di dalam cerita Alkitab yang biasa diadakan pada hari-hari besar agama Kristen.

Butir-butir tersebut hanyalah alternatif. Kreativitas dan inovasi sangat terbuka luas dan bisa dilakukan dalam konteks ibadah etnis tertentu.

\section{Kesimpulan}

Dari pemaparan di atas dapat disimpulkan bahwa 'persilangan' antara colonizer dan colonized dalam konteks musik etnik dalam ibadah kristen bukan semata-mata inkulturasi dua kebudayaan, bukan hanya sekadar kolaborasi musikal yang dapat dinikmati secara estetis, tetapi lebih dari itu merupakan upaya pewartaan Injil Tuhan menuju pertobatan dan suka cita manusia di dalam kasih Allah. Selain itu, ruang ketiga ini dapat pula digunakan sebagai metode musikal dalam rangka menyelamatkan jiwa-jiwa yang belum beriman kepada Kristus_-inilah 'teologi musik'. Masalahnya adalah bagaimana merealisasikan ruang ketiga itu sehingga upaya pertobatan dapat berlangsung secara efektif dan efisien. Lagi-lagi urusannya kembali kepada kreativitas dan inovasi. "Kreativitas" dan "inovasi" adalah dua kata kunci dari upaya pengembangan musik gereja, sehingga melalui kreativitas yang dijiwai semangat Injil itulah gereja dapat berkembang. Inilah tugas yang tidak ringan bagi para musisi gereja yang menyadari eksistensinya. Mereka bukan hanya pemain musik, tetapi lebih dari itu adalah pewarta injil Tuhan karena di dalam konteks musik gereja, apapun alasannya, musik adalah sarana dan bukan tujuan. Tujuan utamanya adalah demi kemuliaan Allah semata.

\section{Kepustakaan}

Adorno, Theodore W. (1985). "Television and Patterns of Mass Culture". Dalam Rosenberg, Bernard \& White, David Manning (Ed.). Mass Culture: The Popular Arts in America. London: Collier Macmillan Publisher. 
Apel, Willi. (1972). Harvard Dictionary of Music. Cambridge: The Belknap Press of Harvard University Press.

Berglund, Robert D. (1985). A Philosophy of Church Music. USA: Library of Congress.

Bhabha, Homi K. (1994). The Location of Culture. New York: Routledge.

Gandhi, Leela. (1998). Teori Poskolonial: Upaya Meruntuhkan Hegemoni Barat, Yuwan Wahyutri dan Nur Hamidah (trans.). Yogyakarta: Qalam.

Gans, Herbet J. (1974). Popular Culture and High Culture. New York: Basic Books, Inc., Publisher.

Hardjana, Suka. (1995). "Catatan Musik Indonesia: Fragmentasi Seni Modern yang Terasing”. Jurnal Kebudayaan Kalam 5.

Huddart, David. (2006). The Perspective of Bhabha's Theories on Humanism. Roudlege Critical Thinkers Series: New York: Roudledge.

Kendrick, Graham. (1984). Pujian dan Penyembahan. Mimery, Phillip (Terj.). Jakarta: Mimery Press.

Lindsay, Jenifer. (1989). Klasik Kitch Kontemporer: Sebuah Studi tentang Seni Pertunjukan Jawa. Soemanto, Nin Bakdi (Terj.). Yogyakarta: Gadjah Mada University Press.

Leo Lowenthal. (1985). "Historical Perspectives of Popular Culture". Dalam Rosenberg, Bernard \& White, David Manning (Ed.). Mass Culture: The Popular Arts in America. London: Collier Macmillan Publisher.

Marinis, Marco de. (1993). The Semiotics of Performance. O'Healy, Aine (trans.). Bloomington: Indiana University Press.

Merriam-Webster's Collegiate Dictionary, Tenth Edition. (1998). Springfield, Massachusetts, USA: Merriam_Webster, Incorporated.

Nettl, Bruno. (1964). Music in Many Culture; Teory and Method in Ethnomusicology. Putra, Nathalian HPD (Terj.). New York: Collier Macmillan Publisher.

. (1983). The Study of Ethnomusicology: Twenty-nine Issues and Concepts. Chicago: University of Illinois Press.

Sudarto. (2000). "Interelasi Nilai Jawa dan Islam dalam Pewayangan". Dalam Amin, Darori (Ed.). Islam dan Kebudayaan Jawa. Yogyakarta: Gama Media.

Supanggah, R. (1995). Etnomusikologi. Yogyakarta: Bentang.

Wolff, Janet. (1993). The Social Production of Art. New York: New York University Press. 